\title{
The impact of land reform on the status of large carnivores in Zimbabwe
}

Samual T Williams, Kathryn S Williams, Christoffel J Joubert, Russell A Hill

Large carnivores are decreasing in number due to growing pressure from an expanding human population. It is increasingly recognised that state-protected conservation areas are unlikely to be sufficient to protect viable populations of large carnivores, and that private land will be central to conservation efforts. In 2000, a fast-track land reform programme (FTLRP) was initiated in Zimbabwe, ostensibly to redress the racial imbalance in land ownership, but which also had the potential to break up large areas of carnivore habitat on private land. To date, research has focused on the impact of the FTLRP process on the different human communities, while impacts on wildlife have been overlooked. Here we provide the first systematic assessment of the impact of the FTLRP on the status of large carnivores. Spoor counts were conducted across private, resettled and communal land use types in order to estimate the abundance of large carnivores, and to determine how this had been affected by land reform. The density of carnivore spoor differed significantly between land use types, and was lower on resettlement land than on private land, suggesting that the resettlement process has resulted in a substantial decline in carnivore abundance. Habitat loss and high levels of poaching in and around resettlement areas are the most likely causes. The FTLRP resulted in the large scale conversion of land that was used sustainably and productively for wildlife into unsustainable, unproductive agricultural land uses. We recommended that models of land reform should consider the type of land available, that existing expertise in land management should be retained where possible, and that resettlement programmes should be carefully planned in order to minimise the impacts on wildlife and on people. 
1 Title: The Impact of Land Reform on the Status of Large Carnivores in Zimbabwe

\section{Abstract}

3 Large carnivores are decreasing in number due to growing pressure from an expanding human

4 population. It is increasingly recognised that state-protected conservation areas are unlikely to be

5 sufficient to protect viable populations of large carnivores, and that private land will be central to

6 conservation efforts. In 2000, a fast-track land reform programme (FTLRP) was initiated in

7 Zimbabwe, ostensibly to redress the racial imbalance in land ownership, but which also had the

8 potential to break up large areas of carnivore habitat on private land. To date, research has

9 focused on the impact of the FTLRP process on the different human communities, while impacts

on wildlife have been overlooked. Here we provide the first systematic assessment of the impact

11 of the FTLRP on the status of large carnivores. Spoor counts were conducted across private,

12 resettled and communal land use types in order to estimate the abundance of large carnivores,

13 and to determine how this had been affected by land reform. The density of carnivore spoor

14 differed significantly between land use types, and was lower on resettlement land than on private

15 land, suggesting that the resettlement process has resulted in a substantial decline in carnivore

16 abundance. Habitat loss and high levels of poaching in and around resettlement areas are the

17 most likely causes. The FTLRP resulted in the large scale conversion of land that was used

18 sustainably and productively for wildlife into unsustainable, unproductive agricultural land uses.

19 We recommended that models of land reform should consider the type of land available, that

20 existing expertise in land management should be retained where possible, and that resettlement

21 programmes should be carefully planned in order to minimise the impacts on wildlife and on

22 people. 
24 Authors: Samual T. Williams ${ }^{1,2,3}$, Kathryn S. Williams ${ }^{1,2}$, Christoffel J. Joubert ${ }^{4}$, Russell A.

25 Hill $^{1,2}$

Affiliations: ${ }^{1}$ Department of Anthropology, Durham University, Dawson Building, South Road,

Durham, DH1 3LE, United Kingdom; ${ }^{2}$ Primate and Predator Project, Lajuma Research Centre, PO Box 522, Louis Trichardt 0920, South Africa; ${ }^{3}$ Dambari Wildlife Trust, PO Box 3863 ,

Bulawayo, Zimbabwe; ${ }^{4}$ Selati Game Reserve, PO Box 296, Gravelotte 0895, South Africa.

Corresponding author: Samual Thomas Williams, Primate and Predator Project, Lajuma

Research Centre, PO Box 522, Louis Trichardt 0920, South Africa; email

s.t.williams@durham.ac.uk; phone +27 717933970.

Keywords: Land reform; Carnivore; Zimbabwe; Africa; Spoor; Resettlement

\section{Introduction}

Large-bodied mammals of the order Carnivora (hereafter referred to as large carnivores) are

culturally important to humans; their body parts are used in ceremonies and traditional medicine

41 and they feature in storytelling, mythology and witchcraft (Kruuk, 2002). Large carnivores are depicted in artworks, on currencies, on coats of arms and on the kits of sport teams (Loveridge et al., 2010). They provide important ecosystem services such as helping to maintain wildlife

44 abundance and richness, and enhancing carbon storage (Ripple et al., 2014). They can also bring 45 in large revenues through tourism (Barnes, 2001; Lindsey et al., 2007) and hunting (Jorge et al., 
46 2013; Lindsey et al., 2006), but they can be a financial burden through predation on livestock

47 (Rust \& Marker, 2014).

48

49 Despite their value, large carnivores across the world are in decline (along with their prey:

Ripple et al., 2015) as a result of the growing human population and increasing pressures on the

environment (Di Marco et al., 2014; Gittleman, Macdonald \& Wayne, 2001; Nowell \& Jackson,

1996; Ray, Hunter \& Zigouris, 2005; Woodroffe, 2000), and they are particularly vulnerable to anthropogenic disturbance (Ray, Hunter \& Zigouris, 2005; Sillero-Zubiri \& Laurenson, 2001).

Many protected areas have failed to sufficiently protect large mammals from anthropogenic

threats (Craigie et al., 2010; Lindsey et al., 2014), and the persistence of national parks alone may not be sufficient to safeguard even species that are relatively abundant in protected areas (Child, 2009a). The importance of land outside of state-protected areas to biodiversity conservation is therefore becoming increasingly clear (Bond et al., 2004; Fjeldså et al., 2004; Kent \& Hill, 2013).

61 Large scale privately owned land is often much more extensive than state protected areas and generally has a relatively low human population density (de Villiers, 2003; du P. Bothma, Suich \& Spenceley, 2009; Lindsey et al., 2013a; Lindsey et al., 2013b; Odendaal, 2006; Scoones et al.,

64 2010), so is capable of supporting relatively large wildlife populations (Child, 2009c; Lindsey et al., 2013b). For example, before 2000, 30\% of the land area of Zimbabwe was composed of

66 large-scale private farms ( $20 \%$ of which were managed specifically for wildlife), while state

67 protected reserves occupied just 13\% of the country (Table 1; du Toit, 2004; Scoones et al., 68 2010). As a result, private land supported substantial wildlife populations, including $80 \%$ of the 
69 cheetahs (Acinonyx jubatus) in Zimbabwe (Stuart \& Wilson, 1988). Other species such as wild

$70 \operatorname{dog}($ Lycaon pictus) and brown hyaena (Parahyaena brunnea), which, like cheetahs, are

71 outcompeted by larger carnivores in national parks (Durant, 1998; Mills, 1990; Woodroffe \&

72 Ginsberg, 2005), also occurred in relatively large numbers on private land in Zimbabwe and

73 other countries (Creel \& Creel, 1996; Kent \& Hill, 2013; Pole, 2000; Stuart \& Wilson, 1988).

75 Much of the prime agricultural land in Zimbabwe was alienated by the colonial administration and gazetted as private land, leaving much of the poorer quality land as communal land

77 (Kwashirai, 2009; Wels, 2003). At independence in 1980, communal land made up 41.9\% of Zimbabwe's land area, and was settled by Africans who largely practiced subsistence agriculture (Scoones et al., 2010). In contrast, Zimbabweans of European descent (an ethnic minority) owned almost all of the large scale private land, which comprised $36.6 \%$ of the land area, and was used primarily for commercial agriculture (Scoones et al., 2010). Since independence in 1980, efforts have been made in Zimbabwe to redress the racial imbalance in land tenure.

Progress, however, had been slow (Clover \& Eriksen, 2009), partly because the commercial farms on private land were highly productive, enhancing food security and providing employment for approximately a third of the Zimbabwean workforce (Kwashirai, 2009; Magaramombe, 2010). Between 1980 and 2000, resettlement occurred through a relatively organised process, with the government purchasing available properties on a willing-seller, willing-buyer basis, or later by compulsory acquisition (Spierenburg, 2011). Criteria for

89 resettlement included underutilisation, absentee or multiple ownership of properties, and 90 proximity to communal areas. 
92 In 2000, Zimbabwe entered the fast-track phase of its land reform programme, whereby private

93 land was redistributed to African settlers, often taken by force and without payment of

94 compensation for the land (Cliffe et al., 2011; Hughes, 2010). While some observers portrayed

95 this as a grassroots movement, many others contended that this was organised by the government

96 in order to destabilise the perceived support base for the opposition party (Chari, 2013; Willems,

97 2004; Zunga, 2003). This resulted in haphazard resettlement of large areas of private land (Table

98 1), most of which was then utilised for subsistence agriculture by communities (Scoones et al.,

99 2010). The new farmers cleared much of their land, but many lacked the resources, support,

100 experience or training necessary to farm effectively (DeGeorges \& Reilly, 2007; Fakarayi et al.,

101 2015; Scoones et al., 2010). The impacts of this violent process on socio-economic factors has

102 been well documented (Chimhowu \& Hulme, 2006; Cliffe et al., 2011; Kapp, 2009; Kinsey,

103 2004; Magaramombe, 2010; Waterloos \& Rutherford, 2004), but despite the great potential for

104 impacting on wildlife, there have been no systematic studies of the impacts of land reform on the 105 status of wildlife (Purchase et al., 2007; Williams, 2007).

107 This study uses the partial resettlement of Savé Valley Conservancy (SVC; Fig. 1) in south east

108 Zimbabwe as a case study to determine the impact of land reform on the status of cheetah,

109 leopard (Panthera pardus), lion (Panthera leo), wild dog, brown hyaena, and spotted hyaena

110 (Crocuta crocuta). The impact that land reform had on the status of large carnivores in SVC

111 between 2000 and 2008 is then evaluated through an assessment of the population sizes of large

112 carnivores in private, fast-track resettlement (hereafter referred to as resettlement) and communal

113 land use types (LUTs). 


\section{Materials \& Methods}

116 The study area was made up of three LUTs in south-eastern Zimbabwe (central coordinates $20^{\circ}$

$11722^{\prime} \mathrm{S}$ and $\left.31^{\circ} 56^{\prime} \mathrm{E}\right)$ : private, resettlement and communal. The private LUT study area was the

118 Savé Valley Conservancy (SVC), a private game reserve that originally covered approximately

$1193,490 \mathrm{~km}^{2}$ (Fig. 1), constituting 10.3\% of the remaining private land in Zimbabwe. SVC was

120 established from former cattle ranches as a cooperatively managed wildlife area (Lindsey et al.,

121 2009), a process catalysed by the reintroduction of black rhinoceros (Diceros bicornis) as part of

122 the government's conservation strategy, the difficulties of farming livestock in such a drought-

123 prone area and the greater profitability of wildlife in relation to cattle in semi-arid environments

124 (Child, 2009b; Lindsey et al., 2009; Price Waterhouse, 1994). Trophy hunting became the main

125 economic activity in SVC (Lindsey et al., 2009), as previously successful ecotourism proved

126 unviable after the collapse of Zimbabwe's tourist industry due to the civil unrest associated with

127 the FTLRP (Mkono, 2012).

128

129 In 2000 and 2001 an area of SVC measuring $960 \mathrm{~km}^{2}$ was resettled as part of the FTLRP,

130 reducing the area of SVC to $2,530 \mathrm{~km}^{2}$. The criteria for selection of the properties for

131 resettlement were not transparent (Chaumba, Scoones \& Wolmer, 2003) and there were no

132 apparent differences between the properties that were resettled and their neighbours that were not

133 resettled in terms of habitat, rainfall, or the density of wildlife perceived by the landowners

134 before resettlement (Williams, 2011). The communal LUT study area was made up of an area of

$135715 \mathrm{~km}^{2}$ of communal land located to the west of SVC. To the south of SVC private game

136 reserves and private farms link the study site to Gonarezhou National Park and the Greater 
137 Limpopo Transfrontier Park. Communal lands make up most of the remainder of the borders of 138 SVC.

140 The topography of the region is gently undulating, with gneiss, Para gneiss and granite outcrops

141 rising up to $250 \mathrm{~m}$ above ground (Pole, 2000), and an elevation of 480-620m above sea level

142 (Pole et al., 2004). Soil quality is poor and rainfall is low (474-540mm per annum) and highly

143 variable, with a wet season between November and March and a dry season between April and

144 October (Lindsey et al., 2009; Pole et al., 2004). The main vegetation type is deciduous

145 woodland savannah, with Colophospermum mopane, Acacia tortillas and Acacia-Combretum

146 woodlands, and riparian vegetation along the watercourses (Pole et al., 2004). The study site falls

147 into the Zambezian and mopane woodlands ecoregion (Olson et al., 2001).

148

149 Spoor counts were conducted in October and November 2008 along existing gravel roads. Spoor 150 counts are a widely used method of estimating the density and abundance of carnivores (Balme,

151 Hunter \& Slotow, 2009; Bauer et al., 2014; Boast \& Houser, 2012; Crooks, 2002; Deryabina et

152 al., 2015; Fritz et al., 2003; Funston, 2001; Groom, Funston \& Mandisodza, 2014; Gusset \&

153 Burgener, 2005; Houser, Somers \& Boast, 2009; Johnson et al., 2010), and can provide robust

154 estimates across a wide variety of species and a broad geographical range (Funston et al., 2010;

155 Midlane et al., 2015). Roads on which spoor were sampled were generally composed of

156 substrates that preserved spoor well such as hard sand (Stuart \& Stuart, 2003). A vehicle was

157 driven at a steady speed of $20 \mathrm{~km} / \mathrm{h}$ in the early morning (generally between 05:00 and 08:00),

158 following Stander (1998). An experienced tracker sat on the front of the vehicle while scanning

159 the transect for spoor, and stopping the vehicle to examine any spoor of large carnivores 
160 encountered. Transects were driven towards the sun where possible in order to facilitate the

161 detection and identification of spoor (Liebenberg, Louw \& Elbroch, 2010). The species, number

162 of individuals and location of each spoor was recorded. Spoor were disregarded if they were over

16324 hours old or if the spoor were thought to be from an individual that had been recorded earlier

164 on the transect that day, which was determined from spoor morphology, group size and direction

165 of travel (Bauer et al., 2014; Funston et al., 2010; Stander, 1998).

166

167 The relationship between spoor frequency (the number of kilometres of transect driven between

168 records of spoor of a particular species) and sampling effort (the number of spoor recorded) was

169 investigated through bootstrap analyses on inter-spoor intervals (the distance between each spoor

170 observation for a particular species, when transects are systematically combined). This was

171 conducted by calculating $95 \%$ confidence intervals from two randomly sampled inter-spoor

172 intervals with replacement, then progressively increasing the sample size and calculating fresh

173 confidence intervals with each sample (after Stander, 1998) using R version 3.2.0 (R

174 Development Core Team, 2015). The code used for bootstrap analysis is available from Williams

175 (2015a). This made it possible to determine whether sufficient data had been collected to reach

176 the preferred levels of variation and sampling precision (Stander, 1998).

177

178 Carnivore spoor density is correlated with population density (Funston et al., 2010). Spoor

179 density at the study site was used to estimate the population density and size of carnivores at

180 SVC by applying the models developed by Stander (1998) (see Williams (2011) for a discussion

181 of model selection). This applies a linear function to spoor density to calculate population 
182 density, using calibration data from study sites with known spoor densities and population

183 densities of study animals.

184

185 The raw data analysed in this study is available in Williams (2015b). The research had approval

186 from both the Durham University Department of Anthropology Departmental Ethics Committee, 187 and the Durham University Life Sciences Ethical Review Process Committee.

\section{Results}

190 Across 1,036 km of transects, a total of 65 lion, 101 leopard, 10 cheetah, 129 wild dog, 12 brown

191 hyaena and 106 spotted hyaena spoor were collected. Sample penetration (the ratio of sum of

192 transect lengths $(\mathrm{km})$ to survey area $\left.\left(\mathrm{km}^{2}\right)\right)$ for most LUTs was close to the value of 7

193 recommended for these techniques (Stander, 1998) (Table 2). Bootstrap analyses on transects in

194 the private LUT (in which almost all spoor were recorded) showed that variation in spoor

195 frequency stabilized at approximately 30 spoor for lion, leopard, cheetah, brown hyaena and

196 spotted hyaena, and at 60 spoor for wild dogs (Fig. 2). These sample sizes were not met for

197 cheetah or brown hyaena spoor, resulting in large confidence intervals for these species.

198 Sampling precision initially increased sharply, but changed little after 30 spoor for lion, leopard

199 and spotted hyaena (Fig. 3; mean change 15\% between 30 spoor and 65 spoor, the minimum

200 sample size collected for these species). Sample sizes for cheetah and wild dog spoor were too

201 small for sampling precision to stabilize. The desired level of precision and variation was

202 therefore reached for most species. Estimation of population size was still conducted for all

203 species but levels of variation and sampling precision were taken into account in interpretation of 204 the results. 
206 Spoor from all large carnivore species were recorded in the private LUT, while only spoor from

207 spotted hyaenas were detected in the resettlement LUT, and no large carnivore spoor were

208 recorded in the communal LUT (Table 3). Spoor densities (defined as the number of carnivore

209 spoor per $100 \mathrm{~km}$ of transect) differed significantly between land use types (Kruskal-Wallis: $\chi^{2}=$

$21014.087, \mathrm{df}=2, \mathrm{P}=0.01)$, and were greater in the private LUT than the resettlement and

211 communal LUTs (Table 3). The private LUT was estimated to support 11 cheetah, 193 leopard,

21272 lion, 142 wild dog, 114 spotted hyaena and 13 brown hyaena (Table 3). In contrast in the

213 resettlement LUT only 6 spotted hyaena were estimated to occur, while the communal LUT

214 supported no large carnivores (Table 3).

215

\section{Discussion}

217 In 2000 and 2001, approximately $40 \%$ of SVC was resettled as part of the FTLRP. In 2008, large

218 carnivore densities in the remaining private LUT were comparable to those found in protected

219 areas elsewhere (Bailey, 2005; Bauer \& Van Der Merwe, 2004; Ivan, White \& Shenk, 2013;

220 Mills \& Hofer, 1998; Thorn et al., 2009; Woodroffe, McNutt \& Mills, 2004). In contrast,

221 carnivores occurred at very low densities or were absent in the resettlement areas and communal

222 LUT.

223

224 Although there are no comparable density estimates from before resettlement, it seems unlikely

225 that the patterns we report were due to low population densities in the resettlement areas prior to

226 resettlement. Sighting frequencies of cheetah on Senuko ranch declined markedly following the

227 onset of the FTLRP and resettlement on other properties in SVC (Williams, 2011), and carrying 
228 capacity estimates for large carnivores based on the biomass of potential prey species from aerial

229 surveys decreased between 2004 and 2008 (Williams, 2011). Similarly while animal populations

230 could respond to resettlement through changes in behaviour between the different LUTs,

231 reducing group size and use of roads (and thus spoor frequency) (Stillfried et al., 2015), this

232 should not influence prey biomass estimates and carrying capacity estimates from aerial surveys.

233 A difference in the population density of large carnivores between LUTs resulting directly from

234 resettlement is the most likely explanation for our results.

235

236 The absence or low densities of large carnivores in the resettlement and communal LUTs can be

237 explained by high human densities, which led to pressure for land to grow crops and graze

238 livestock, resulting in a loss of habitat and prey base. In the private LUT human population

239 density was low, habitat was still comparatively intact and prey was relatively abundant. Even

240 so, carnivore population sizes appear to have been below carrying capacity estimates based on

241 prey availability and rainfall (Williams, 2011), although this may have been partially do to the

242 fact that carnivore populations were still thought to be recovering from their low densities before

243 SVC was formed (Lindsey et al., 2009).

245 The low carnivore densities in the resettlement LUT are most likely the result of a population

246 decline in response to the resettlement process, rather than migration of animals out of

247 resettlement areas. If this were the case, we would expect to find greater densities of wildlife on

248 private land near to resettlement areas, but the opposite trend was observed (Williams, 2011). No

249 evidence was found of carnivore populations moving from the resettlement areas to the 
250 communal land surrounding SVC. A more likely explanation is population declines precipitated

251 by extensive bushmeat poaching (Lindsey et al., 2011b).

252

253 The extremely high levels of poaching in SVC were the result of a large human population being

254 settled on private land with large wildlife populations, and were exacerbated by Zimbabwe's

255 economic crisis and food shortages arising from the FTLRP (Knapp, 2012; Lindsey et al., 2011a;

256 Moss, 2007), limiting carnivore abundance in the private LUT. Poaching rates in SVC increased

257 to extremely high levels after the FTLRP began; between August 2001 and June 2009 over

25884,000 snares were removed and 4,148 poachers were captured (Lindsey et al., 2011b). The

259 remains of 6,454 poached animals were recovered, including 2 cheetahs, 5 leopards and, 27 wild

260 dogs (Lindsey et al., 2011b). Numerous individuals of prey species were also recovered during

261 this period, such as 2,606 impala (Lindsey et al., 2011b), which would reduce carnivore carrying

262 capacity through removal of the prey base (Hayward, O'Brien \& Kerley, 2007). Within the

263 private LUT, rates of poaching per unit area were over 2.5 times higher in the south than the

264 north (Lindsey et al., 2011b), which is probably linked to greater proximity to the resettlement

265 area (Fig. 1). When resettlement occurred the perimeter game fencing was stolen, facilitating

266 access of poachers from the resettlement area to southern SVC and providing abundant material

267 to manufacture snares (Lindsey et al., 2009). While fencing can be an incredibly useful tool for

268 managing wildlife populations (Packer et al., 2013), it is important to use material that cannot be

269 easily used to manufacture snares (such as Veldspan ${ }^{\mathrm{TM}}$ or Bonnox $^{\mathrm{TM}}$ ), rather than the steel and

270 barbed wire that was used to construct the fence at SVC (Lindsey et al., 2012).

271 
272 Within SVC land resettlement has thus had a large impact on large carnivore populations. Land

273 resettlement was widespread in Zimbabwe, however, and most of the other large scale

274 conservancies in Zimbabwe including Gwayi, Bubiana and Chiredzi River conservancies have

275 also been severely affected by the FTLRP (du Toit, 2004; Lindsey et al., 2011b), with very few

276 (such as Malilangwe Trust) remaining untouched (Lindsey et al., 2011b). In addition to

277 conservancies, almost all other private land was resettled, so if the trends at SVC are indicative

278 of trends across Zimbabwe, this could have severe impacts on the status of large carnivores.

279 While a small proportion of resettled land may have been retained for wildlife-based uses, a

280 preliminary extrapolation of our findings suggests that Zimbabwe's FTLRP could have had a

281 significant negative impact on the population size of large carnivores at a national scale,

282 resulting in estimated population declines of an average of $36 \%$, up to a maximum of $70 \%$,

283 across the country, depending on the species (Article S1). Species that depend on private land to

284 a greater extent, such as cheetah, are likely to have been more strongly affected than species such

285 as lions, whose populations are concentrated in protected areas. This combination of potential

286 steep population declines and disrupted connectivity throughout the Greater Limpopo

287 Transfrontier Park, brought about by resettlement removing corridors and links between national

288 parks, calls into question the viability of the remaining populations of some species in

289 Zimbabwe; relatively large populations of up to several thousand individuals are thought to be

290 required in order to maintain genetic viability (Crooks, 2002; Lande, 1995). In addition to

291 affecting wildlife populations, the FTLRP is likely to have resulted in wide scale loss of the jobs

292 (Lindsey et al., 2013a; Lindsey, Roulet \& Romañach, 2007), community benefits (Le Bel et al.,

293 2013), food security (Cumming, 2005) and income through tourism (Naidoo et al., in press) or

294 hunting (Lindsey et al., 2006) associated with the wildlife industry. 
296 A key factor that enabled the wildlife industry to become so important and the wildlife

297 populations to become so abundant on private land in Zimbabwe and other countries in southern

298 Africa, was the introduction of legislation devolving rights to utilise wildlife on private land to

299 the landowners (Bond et al., 2004). This allowed landowners to exploit a ready market of

300 photographic tourists (Naidoo et al., in press) and trophy hunters (Lindsey et al., 2006; Lindsey,

301 Roulet \& Romañach, 2007), while encouraging landowners to manage their land to maximise

302 wildlife populations, leading to significant growth in the occupancy of wildlife populations

303 (Child, 2009b). In the semi-arid areas in which most land managed for wildlife occurred, wildlife

304 was the most appropriate land use in terms of economic productivity (Child, 2009b),

305 employment (Bond et al., 2004), and environmental conservation (Bond et al., 2004), and rain-

306 fed agriculture was not recommended (Vincent \& Hack, 1960). The FTLRP ignored the reasons

307 for the shift from agriculture to wildlife and resulted in the replacement of viable wildlife

308 operations with unsuitable farming practices. While the beneficiaries of the FTLRP did accrue

309 benefits such as access to land and natural resources (Scoones et al., 2010), this came at great

310 cost to both society and biodiversity conservation.

312 The negative impacts of land reform on the status of large carnivores documented here could be

313 reduced by modifying the way in which land reform programmes are implemented. Firstly, the

314 model of land reform that was applied under Zimbabwe's FTLRP considered agricultural models

315 at the expense of a wildlife-based model. The agricultural land reform models applied were

316 poorly suited to the arid and semi-arid areas in which many private wildlife and livestock

317 ranches were located (Child, 1995; Vincent \& Hack, 1960), and when combined with poor 
318 availability of resources for the new farmers this contributed to crop failure (DeGeorges \&

319 Reilly, 2007). If a wildlife-based land reform model could be applied, whereby private wildlife

320 ranches retain wildlife as a land use but a more representative ethnic profile of landowners is

321 achieved, this could result in stronger wildlife populations, be more ecologically sustainable,

322 provide greater profits (Child et al., 2012; Price Waterhouse, 1994) and lead to lower levels of

323 human-wildlife conflict (Williams, 2011). It appears that this has started to happen, changing the

324 way in which the government addresses land reform (Scoones et al., 2012), but care must be

325 taken to ensure that this is done in a sustainable way.

326

327 Planning is critical to minimising the impact of land reform on wildlife and human-wildlife

328 conflict. Many problems could be avoided by considering wildlife when planning land reform,

329 such as by maintaining connectivity between wildlife populations (Bennett, 2003) and reducing

330 edge effects by minimising the boundary between resettlement and wildlife areas (Balme, Slotow

331 \& Hunter, 2010; Woodroffe \& Ginsberg, 1998). Where resettlement has already fragmented

332 habitats (du Toit, 2004), wildlife corridors could be re-established to link separated populations

333 and enhance their viability (Bennett, 2003). Any wildlife remaining in the areas of resettlement

334 land that became reincorporated into SVC as wildlife corridors could be owned by the

335 communities resettled in the area and jointly managed by the community members and SVC.

336 Funds raised through utilisation of this wildlife resource could go back to the community,

337 enabling them to benefit from conserving wildlife on their land.

338

339 Allowing local communities to benefit economically from the wildlife in SVC, for example

340 through schemes like CAMPFIRE (Frost \& Bond, 2008; Taylor, 2009a; Taylor, 2009b), would 
341 create an incentive for them to protect wildlife populations in the area and reduce the need for

342 people to turn to poaching (Campbell, 2000). Indeed this is now happening; for example, a trust

343 has been established to purchase wildlife breeding stock on behalf of the neighbouring

344 communities to be placed in SVC (Kreuter, Peel \& Warner, 2010). The offspring are sold to

345 SVC, providing a regular income to the communities.

347 Other innovative mechanisms for involving communities in conservation on private land have

348 been explored in South Africa. For example, game reserves such as Phinda and Mala Mala were

349 claimed by communities, who then leased the land back to the reserve mangement, maintaining

350 wildlife as the land use and retaining the expertise and capital of the former owners, but bringing

351 revenue to the community (Masombuka, 2015; Spenceley \& Rylance, 2012). Similar

352 programmes have also been successful in national parks. Sections of Kruger National Park and

353 the Kgalagadi Transfrontier Park in South Africa have been claimed by communities, who were 354 granted legal ownership of the land. The communities now manage the land under a contractual

355 agreement with the government, and retain the rights to commercial development such as tourist

356 lodges (Grossman \& Holden, 2009). Raising funds to allow communities to buy shareholdings in

357 SVC would enhance community participation in the conservancy and allow them to benefit

358 either through paying dividends to community members or by funding community projects such

359 as schools, clinics or irrigation projects (Taylor, 2009a). Another option is to expand private

360 reserves to include community land. This has been undertaken at SVC, whereby $25 \mathrm{~km}^{2}$ of cattle

361 grazing land was set aside and became part of the conservancy (Lindsey et al., 2009).

362 Partnerships between communities and the private sector such as these could provide a more

363 durable land use model than the largely exclusive ownership of extensive areas of land by a 
364 minority ethnic group, and models such as these may prove to be a sustainable solution to the

365 land reform issue. If authorities could provide greater security of land tenure to beneficiaries of

366 the FTLRP, attitudes towards wildlife may become more positive (Romañach, Lindsey \&

367 Woodroffe, 2007), which could also lead to reduced rates of poaching (Hartter \& Goldman

368 2011).

369

370 We suggest that further research is conducted to determine that the trends observed at the study

371 site are representative at national and international levels, and whether carnivore populations in

372 Zimbabwe are continuing to decrease further. Land reform initiatives are also underway in other

373 countries that had extensive areas of private land such as South Africa and Namibia. Before land

374 reform programmes were initiated (de Villiers, 2003; Kepe, Wynberg \& Ellis, 2005; Lahiff,

375 2014), private land constituted $72 \%$ and $44 \%$ of the total land area of South Africa and Namibia

376 respectively (Adams \& Howell, 2001). The pace of redistribution, however, has again been slow,

377 with only approximately $1 \%$ of private land in South Africa and Namibia being redistributed by

3782000 (Adams \& Howell, 2001), prompting some stakeholders to call for a more radical approach

379 such as the Zimbabwean model of land reform (de Villiers, 2003; O'Laughlin et al., 2013). With

380 land reform remaining an important issue around the world (Adam, 2013; Diniz et al., 2013;

381 Nyahunzvi, 2014; Pellegrini \& Dasgupta, 2011; Vilpoux, 2014), the recommendations of this

382 study could help to prevent the socio-economic and wildlife issues that Zimbabwe has

383 encountered from being repeated elsewhere. 


\section{Conclusions}

386 Land reform appears to have significantly reduced the population size of large carnivores in SVC.

387 Very high levels of poaching and a decline in prey base associated with land reform are thought

388 to be responsible for these declines. This case study could be indicative of broader trends across

389 Zimbabwe. We recommended that care is taken to carefully plan land reform programmes in

390 other countries in order to minimise the negative effects on wildlife populations and maintain

391 linkages where possible. Retaining wildlife as a land use, while employing innovative models

392 that retaining existing expertise and capital, would go a long way towards allowing both wildlife

393 and people to benefit from land reform.

\section{Acknowledgements}

396 The African Wildlife Conservation Fund very kindly allowed the spoor data they collected to be

397 used towards this analysis. We thank the authorities that granted permission to conduct the

398 research and to the participants for taking part in the study. We would also like to thank the

399 landowners, managers, and workers of Savé Valley Conservancy, particularly on Chishakwe and

400 Humani, for their hospitality and support. Many thanks to Rueben Bote and Misheck Matari for

401 doing an amazing job as trackers and to Phil Stephens for writing the R script used for

402 bootstrapping. Finally, we are grateful to three anonymous reviewers for providing very valuable

403 comments and strengthening the manuscript. 


\section{References}

406 Adam J. 2013. Land reform, dispossession and new elites: a case study on coconut plantations in 407 Davao Oriental, Philippines. Asia Pacific Viewpoint 54:232-245.

408 Adams M, and Howell J. 2001. Redistributive land reform in Southern Africa. Natural Resource 409 Perspectives 64:1-6.

410 Bailey TN. 2005. The African leopard: ecology and behavior of a solitary felid. Caldwell:

$411 \quad$ Blackburn Press.

412 Balme GA, Hunter LT, and Slotow R. 2009. Evaluating methods for counting cryptic carnivores. 413 The Journal of Wildlife Management 73:433-441.

414 Balme GA, Slotow R, and Hunter LTB. 2010. Edge effects and the impact of non-protected areas 415 in carnivore conservation: leopards in the Phinda-Mkhuze Complex, South Africa. Animal Conservation 13:315-323.

417 Barnes J. 2001. Economic returns and allocation of resources in the wildlife sector of Botswana. South African Journal of Wildlife Research 31:141-153.

419 Bauer D, Schiess-Meier M, Mills DR, and Gusset M. 2014. Using spoor and prey counts to 420 determine temporal and spatial variation in lion (Panthera leo) density. Canadian Journal of Zoology:97-104.

Bauer H, and Van Der Merwe S. 2004. Inventory of free-ranging lions Panthera leo in Africa. Oryx 38:26-31.

Bennett AF. 2003. Linkages in the landscape: the role of corridors and connectivity in wildlife conservation. Gland: IUCN.

Boast LK, and Houser A. 2012. Density of large predators on commercial farmland in Ghanzi, 427 Botswana. South African Journal of Wildlife Research 42:138-143. 
428 Bond I, Child B, de la Harpe D, Jones B, Barnes J, and Anderson H. 2004. Private land contribution to conservation in South Africa. In: Child B, ed. Parks in transition: biodiveristy, rural development, and the bottom line. London: Earthscan, 29-61.

431

432

433

Campbell B. 2000. Animals behaving badly: indigenous perceptions of wildlife protection in Zimbabwe. In: Knight J, ed. Natural enemies: people-wildlife conflict in anthropological perspective. London: Routledge, 124-144.

Chari T. 2013. Media framing of land reform in Zimbabwe. In: Moyo S, and Chambati W, eds. Land and Agrarian Reform in Zimbabwe Beyond White-Settler Capitalism. Dakar: CODESRIA and AIAS, 291-329.

Chaumba J, Scoones I, and Wolmer W. 2003. From jambanja to planning: the reassertion of technocracy in land reform in south-eastern Zimbabwe? Journal of Modern African Studies 41:533-554.

Child B. 2009a. The emergence of parks and conservation narratives in southern Africa. In: Child B, Suich H, and Spenceley A, eds. Evolution and innovation in wildlife conservation in southern Africa. London: Earthscan, 19-33.

Child B. 2009b. Game ranching in Zimbabwe. In: Child B, Suich H, and Spenceley A, eds. Evolution and innovation in wildlife conservation in southern Africa. London: Earthscan, 127-145.

Child B. 2009c. Private conservation in Southern Africa: practice and emerging principles. In: Child B, ed. Parks in transition: biodiversity, rural development, and the bottom line. London: Earthscan, 103-111.

Child BA, Musengezi J, Parent GD, and Child GF. 2012. The economics and institutional economics of wildlife on private land in Africa. Pastoralism 2:1-32. 
451 Child G. 1995. Wildlife and people: the Zimbabwean success. Harare: Wisdom Foundation.

452 Chimhowu A, and Hulme D. 2006. Livelihood dynamics in planned and spontaneous

453 resettlement in Zimbabwe: converging and vulnerable. World development 34:728-750.

454 Cliffe L, Alexander J, Cousins B, and Gaidzanwa R. 2011. An overview of Fast Track Land Reform in Zimbabwe: editorial introduction. Journal of Peasant Studies 38:907-938.

456

457

458

459

460

461

462

463

464

465

466

467

468

469

470

471

472

473

Clover J, and Eriksen S. 2009. The effects of land tenure change on sustainability: human security and environmental change in southern African savannas. Environmental Science \& Policy 12:53-70.

Craigie ID, Baillie JEM, Balmford A, Carbone C, Collen B, Green RE, and Hutton JM. 2010. Large mammal population declines in Africa's protected areas. Biological Conservation $143: 2221-2228$.

Creel S, and Creel NM. 1996. Limitation of African wild dogs by competition with larger carnivores. Conservation Biology 10:526-538.

Crooks KR. 2002. Relative sensitivities of mammalian carnivores to habitat fragmentation. Conservation Biology 16:488-502.

Cumming D. 2004. Performance of parks in a century of change. In: Child B, ed. Parks in transition: biodiversity, rural development, and the bottom line. London: Earthscan, 105124.

Cumming D. 2005. Wildlife, livestock and food security in the south east lowveld of Zimbabwe. In: Osofsky SA, Cleaveland S, Karesh WB, Kock MD, Nyhus PJ, Starr L, and Yang A, eds. Conservation and development interventions at the wildlife/livestock interface: implications for wildlife, livestock and human health. Gland and Cambridge: Occasional paper of the IUCN Species Survival Commission No. 30, 41-45. 
474 de Villiers B. 2003. Land reform: issues and challenges. A comparative overview of experiences

475 in Zimbabwe, Namibia, South Africa and Australia. Johannesburg: Konrad-Adenauer-

$476 \quad$ Stiftung.

477 DeGeorges A, and Reilly B. 2007. Politicization of land reform in Zimbabwe: impacts on

478 wildlife, food production and the economy. International Journal of Environmental

$479 \quad$ Studies 64:571-586.

480 Deryabina TG, Kuchmel SV, Nagorskaya LL, Hinton TG, Beasley JC, Lerebours A, and Smith

481 JT. 2015. Long-term census data reveal abundant wildlife populations at Chernobyl.

482 Current Biology 25:R824-R826.

483 Di Marco M, Boitani L, Mallon D, Hoffmann M, Iacucci A, Meijaard E, Visconti P, Schipper J, 484 and Rondinini C. 2014. A retrospective evaluation of the global decline of carnivores and 485 ungulates. Conservation Biology 28:1109-1118.

486 Diniz FH, Hoogstra-Klein MA, Kok K, and Arts B. 2013. Livelihood strategies in settlement 487 projects in the Brazilian Amazon: determining drivers and factors within the Agrarian 488 Reform Program. Journal of Rural Studies 32:196-207.

489 du P. Bothma J, Suich H, and Spenceley A. 2009. Extensive wildlife production on private land 490 in South Africa. In: Child B, ed. Parks in transition: biodiversity, rural development, and 491 the bottom line. London: Earthscan, 147-161.

492 du Toit R. 2004. Review of wildlife issues associated with the land reform programme in 493 Zimbabwe. World Wide Fund for Nature (WWF), Southern African Regional Programme Office, Harare.

Durant SM. 1998. Competition refuges and coexistence: an example from Serengeti carnivores. Journal of Animal Ecology 67:370-386. 
497 Fakarayi T, Mashapa C, Gandiwa E, and Kativu S. 2015. Pattern of land-use and land cover

498 changes in Driefontein Grassland Important Bird Area, Zimbabwe. Tropical $499 \quad$ Conservation Science 8:274-283.

500 Fjeldså J, Burgess ND, Blyth S, and De Klerk HM. 2004. Where are the major gaps in the 501 reserve network for Africa's mammals? Oryx 38:17-25.

502 Fritz H, Saïd S, Renaud P-C, Mutake S, Coid C, and Monicat F. 2003. The effects of agricultural 503 fields and human settlements on the use of rivers by wildlife in the mid-Zambezi valley, Zimbabwe. Landscape Ecology 18:293-302.

505 Frost PGH, and Bond I. 2008. The CAMPFIRE programme in Zimbabwe: payments for wildlife services. Ecological Economics 65:776-787.

507

508

509

510

511

512

513

514

515

516

517

518

Funston PJ. 2001. Kalahari Transfrontier Lion Project - Population ecology and long term monitoring of a free-ranging popuation in an arid environment. Endangered Wildlife Trust, Upington.

Funston PJ, Frank L, Stephens T, Davidson Z, Loveridge A, Macdonald DM, Durant S, Packer C, Mosser A, and Ferreira SM. 2010. Substrate and species constraints on the use of track incidences to estimate African large carnivore abundance. Journal of Zoology 281:56-65.

Gittleman JL, Macdonald DW, and Wayne RK. 2001. Why 'carnivore conservation'? In:

Gittleman JL, Funk SM, Macdonald DW, and Wayne RK, eds. Carnivore conservation. Cambridge: Cambridge University Press, 1-7.

Groom RJ, Funston PJ, and Mandisodza R. 2014. Surveys of lions Panthera leo in protected areas in Zimbabwe yield disturbing results: what is driving the population collapse? Oryx 48:385-393. 
519 Grossman D, and Holden P. 2009. Towards transformation: contractual parks in South Africa.

520 In: Child B, Suich H, and Spenceley A, eds. Evolution and innovation in wildlife

521 conservation in southern Africa. London: Earthscan, 357-372.

522 Gusset M, and Burgener N. 2005. Estimating larger carnivore numbers from track counts and 523 measurements. African Journal of Ecology 43:320-324.

524 Hartter J, and Goldman A. 2011. Local responses to a forest park in western Uganda: alternate 525 narratives on fortress conservation. Oryx 45:60-68.

526 Hayward MW, O'Brien J, and Kerley GIH. 2007. Carrying capacity of large African predators:

527 predictions and tests. Biological Conservation 139:219-229.

Houser A, Somers M, and Boast L. 2009. Spoor density as a measure of true density of a known population of free-ranging wild cheetah in Botswana. Journal of Zoology 278:108-115.

Hughes DM. 2010. Whiteness in Zimbabwe: race, landscape, and the problem of belonging. New York: Palgrave Macmillan.

Ivan JS, White GC, and Shenk TM. 2013. Using simulation to compare methods for estimating density from capture-recapture data. Ecology 94:817-826.

534 Johnson WE, Onorato DP, Roelke ME, Land ED, Cunningham M, Belden RC, McBride R, Jansen D, Lotz M, and Shindle D. 2010. Genetic restoration of the Florida panther. Science 329:1641-1645.

537 Jorge AA, Vanak AT, Thaker M, Begg C, and Slotow R. 2013. Costs and benefits of the presence of leopards to the sport-hunting industry and local communities in Niassa National Reserve, Mozambique. Conservation Biology 27:832-843.

540 Kapp C. 2009. Zimbabwe's humanitarian crisis worsens. The Lancet 373:447. 
541 Kent VT, and Hill RA. 2013. The importance of farmland for the conservation of the brown

$542 \quad$ hyaena Parahyaena brunnea. Oryx 47:431-440.

543 Kepe T, Wynberg R, and Ellis W. 2005. Land reform and biodiversity conservation in South Africa: complementary or in conflict? The International Journal of Biodiversity Science and Management 1:3-16.

546

547

548

549

550

551

552

553

Kinsey BH. 2004. Zimbabwe's land reform program: underinvestment in post-conflict transformation. World development 32:1669-1696.

Knapp EJ. 2012. Why poaching pays: a summary of risks and benefits illegal hunters face in Western Serengeti, Tanzania. Tropical Conservation Science 5:434-445.

Kreuter U, Peel M, and Warner E. 2010. Wildlife conservation and community-based natural resource management in southern Africa's private nature reserves. Society and Natural Resources 23:507-524.

Kruuk H. 2002. Hunter and hunted: the relationship between carnivores and people. Cambridge: Cambridge University Press.

Kwashirai VC. 2009. Ecological and poverty impacts of Zimbabwe's land struggles: 1980 to present. Global Environment 2:222-253.

Lahiff E. 2014. Land Reform in South Africa 100 Years after the Natives' Land Act. Journal of Agrarian Change 14:586-592.

Lande R. 1995. Mutation and conservation. Conservation Biology 9:782-791.

Le Bel S, Stansfield F, La Grange M, and Taylor R. 2013. Managing local overabundance of elephants through the supply of game meat: the case of Save Valley Conservancy, Zimbabwe. South African Journal of Wildlife Research 43:103-119. 
563 Liebenberg L, Louw A, and Elbroch M. 2010. Practical tracking: a guide to following footprints 564 and finding animals. Mechanicsburg: Stackpole Books.

565 Lindsey PA, Alexander R, Frank LG, Mathieson A, and Romañach SS. 2006. Potential of trophy 566 hunting to create incentives for wildlife conservation in Africa where alternative wildlifebased land uses may not be viable. Animal Conservation 9:283-291.

Lindsey PA, Alexander R, Mills MGL, Romañach S, and Woodroffe R. 2007. Wildlife viewing preferences of visitors to protected areas in South Africa: Implications for the role of ecotourism in conservation. Journal of Ecotourism 6:19-33.

571

Lindsey PA, Barnes J, Nyirenda V, Pumfrett B, Tambling CJ, Taylor WA, and Rolfes MtS. 2013a. The Zambian wildlife ranching industry: scale, associated benefits, and limitations affecting its development. PLOS ONE 8:e81761.

Lindsey PA, du Toit R, Pole A, and Romañach S. 2009. Savé Valley Conservancy: a large scale African experiment in cooperative wildlife management. In: Child B, Suich $\mathrm{H}$, and Spenceley A, eds. Evolution and innovation in wildlife conservation in southern Africa. London: Earthscan, 163-184.

Lindsey PA, Havemann CP, Lines RM, Price AE, Retief TA, Rhebergen T, Van der Waal C, and Romañach SS. 2013b. Benefits of wildlife-based land uses on private lands in Namibia and limitations affecting their development. Oryx 47:41-53.

Lindsey PA, Masterson CL, Beck AL, and Romañach S. 2012. Ecological, social and financial issues related to fencing as a conservation tool in Africa. In: Somers MJ, and Hayward MW, eds. Fencing for Conservation. New York: Springer, 215-234.

Lindsey PA, Nyirenda VR, Barnes JI, Becker MS, McRobb R, Tambling CJ, Taylor WA, Watson FG, and t'Sas-Rolfes M. 2014. Underperformance of African protected area 
networks and the case for new conservation models: insights from Zambia. PLoS ONE 9:e94109.

Lindsey PA, Romañach SS, Matema S, Matema C, Mupamhadzi I, and Muvengwi J. 2011 a. Dynamics and underlying causes of illegal bushmeat trade in Zimbabwe. Oryx 45:84-95.

Lindsey PA, Romañach SS, Tambling CJ, Chartier K, and Groom R. 2011b. Ecological and financial impacts of illegal bushmeat trade in Zimbabwe. Oryx 45:96-111.

Lindsey PA, Roulet PA, and Romañach SS. 2007. Economic and conservation significance of the trophy hunting industry in sub-Saharan Africa. Biological Conservation 134:455-469.

Loveridge AJ, Wang SW, Frank LG, and Seidensticker J. 2010. People and wild felids: conservation of cats and management of conflicts. In: Macdonald DW, and Loveridge AJ, eds. The biology and conservation of wild felids. Oxford: Oxford University Press, $161-195$.

Magaramombe G. 2010. 'Displaced in place': agrarian displacements, replacements and resettlement among farm workers in Mazowe district. Journal of Southern African Studies 36:361-375.

Masombuka S. 2015. Mala Mala limbo. Times Live. Available at http://www.timeslive.co.za/thetimes/2015/05/04/mala-mala-limbo (accessed 26 Nov 2015).

Midlane N, O’Riain MJ, Balme GA, and Hunter LT. 2015. To track or to call: comparing methods for estimating population abundance of African lions Panthera leo in Kafue National Park. Biodiversity and Conservation:1-17.

Mills G, and Hofer H. 1998. Hyaenas: status survey and conservation action plan. IUCN/SSC Hyaena Specialist Group, Gland. 
609 Mills MGL. 1990. Kalahari hyaenas: the comparative behivioural ecology of two species.

610 Unwin Hyman: London.

611 Mkono M. 2012. Zimbabwe's tourism woes in the last decade: Hindsight lessons for African 612 tourism planners and managers. Tourism Planning \& Development 9:205-210.

613 Moss T. 2007. Zimbabwe's Meltdown: Anatomy of a peacetime economic collapse. Fletcher $614 \quad$ Forum of World Affairs 31:133-148.

615 Naidoo R, Weaver CL, Diggle RW, Matongo G, Stuart-Hill G, and Thouless C. in press.

616 Complementary benefits of tourism and hunting to communal conservancies in Namibia.

617 Conservation Biology.

618 Nowell K, and Jackson P. 1996. Wild cats: status survey and conservation action plan.

$619 \quad$ IUCN/SSC Cat Specialist Group, Gland.

620 Nyahunzvi DK. 2014. The resurgence in resource nationalism and private protected areas:

621 through the lens of Save Valley Conservancy's indigenisation. Journal for Nature

622 Conservation 22:42-49.

623 O'Laughlin B, Bernstein H, Cousins B, and Peters PE. 2013. Introduction: Agrarian Change,

624 Rural Poverty and Land Reform in South Africa since 1994. Journal of Agrarian Change

$625 \quad 13: 1-15$.

626 Odendaal W. 2006. The SADC land and agrarian reform initiative: the case of Namibia. NEPRU 627 working paper no. 111. Namibian Economic Policy Research Unit, Windhoek.

628 Olson DM, Dinerstein E, Wikramanayake ED, Burgess ND, Powell GVN, Underwood EC,

629 D'Amico JA, Itoua I, Strand HE, Morrison JC, Loucks CJ, Allnutt TF, Ricketts TH, Kura

630 Y, Lamoreux JF, Wettengel WW, Hedao P, and Kassem KR. 2001. Terrestrial ecoregions

631 of the worlds: a new map of life on Earth. Bioscience 51:933-938. 
632 Packer C, Loveridge A, Canney S, Caro T, Garnett S, Pfeifer M, Zander K, Swanson A, 633 MacNulty D, and Balme G. 2013. Conserving large carnivores: dollars and fence. $634 \quad$ Ecology Letters 16:635-641.

635 Pellegrini L, and Dasgupta A. 2011. Land reform in Bolivia: the forestry question. Conservation 636 and Society 9:274.

637 Pole A, Gordon IJ, Gorman ML, and MacAskill M. 2004. Prey selection by African wild dogs 638 (Lycaon pictus) in southern Zimbabwe. Journal of Zoology 262:207-215.

639 Pole AJ. 2000. The behaviour and ecology of African wild dogs, Lycaon pictus, in an 640 environment with reduced competitor density. PhD thesis. University of Aberdeen.

641 Price Waterhouse. 1994. The lowveld conservancies: new opportunities for productive and 642 sustainable land-use. Savé Valley, Bubiana and Chiredzi River Conservancies, Harare.

643 Purchase G, Marker L, Marnewick K, Klein R, and Williams S. 2007. Regional assessment of 644 the status, distribution and conservation needs of cheetahs in southern Africa. Cat News special Issue 3: status and conservation needs of cheetahs in southern Africa:44-46.

R Development Core Team. 2015. R: a language and environment for statistical computing [computer program]. Available from http://cran.r-project.org. The R Foundation for Statistical Computing, Vienna.

Ray JC, Hunter L, and Zigouris J. 2005. Setting conservation and research priorities for larger African carnivores. Working paper number 24. Wildlife Conservation Society, New York.

Ripple WJ, Estes JA, Beschta RL, Wilmers CC, Ritchie EG, Hebblewhite M, Berger J, Elmhagen B, Letnic M, Nelson MP, Schmitz OJ, Smith DW, Wallach AD, and Wirsing AJ. 2014. Status and ecological effects of the world's largest carnivores. Science 343. 
655 Ripple WJ, Newsome TM, Wolf C, Dirzo R, Everatt KT, Galetti M, Hayward MW, Kerley GI, 656 Levi T, and Lindsey PA. 2015. Collapse of the world's largest herbivores. Science

657

658

659

660

661

662

663

664

665

666

667

668

669

670

671

672

673

674

675 Advances 1:e1400103.

Romañach S, Lindsey PA, and Woodroffe R. 2007. Determinants of attitudes towards predators in central Kenya and suggestions for increasing tolerance in livestock dominated landscapes. Oryx 41:185-195.

Rust NA, and Marker LL. 2014. Cost of carnivore coexistence on communal and resettled land in Namibia. Environmental Conservation 41:45-53.

Scoones I, Chaumba J, Mavedzenge B, and Wolmer W. 2012. The new politics of Zimbabwe's lowveld: Struggles over land at the margins. African Affairs 111:527-550.

Scoones I, Marongwe N, Mavedzenge B, Mahenehene J, Murimbarimba F, and Sekume C. 2010. Zimbabwe's land reform: myths \& realities. Woodbridge: James Currey.

Sillero-Zubiri C, and Laurenson MK. 2001. Interactions between carnivores and local communities: conflict or coexistence? In: Gittleman JL, Funk SM, Macdonald DW, and Wayne RK, eds. Carnivore conservation. Cambridge: Cambridge University Press, 282312.

Spenceley A, and Rylance A. 2012. Responsible wildlife tourism in Africa. In: Leslie D, ed. Responsible tourism: concepts, theory and practice. Wallingford: CABI Publishing, 130141.

Spierenburg M. 2011. Land reform in southern Africa: myths, visions and the harsh realities of development and justice. Development and Change 42:1473-1481. 
676 Stander PE. 1998. Spoor counts as indices of large carnivore populations: the relationship

677

678

679

680

681

682

683

684

685

686

687

688

689

690

691

692

693

694

695

696

697

between spoor frequency, sampling effort and true density. Journal of Applied Ecology $35: 378-385$.

Stillfried M, Belant JL, Svoboda NJ, Beyer DE, and Kramer-Schadt S. 2015. When top predators become prey: black bears alter movement behaviour in response to hunting pressure. Behavioural Processes 120:30-39.

Stuart C, and Stuart T. 2003. A field guide to the tracks and signs of southern and east African wildlife. Cape Town: Struik.

Stuart CT, and Wilson VJ. 1988. The cats of southern Africa. Bulawayo: The Chipangali Wildlife Trust.

Taylor R. 2009a. Community based natural resource management in Zimbabwe: the experience of CAMPFIRE. Biodiversity and Conservation 18:2563-2583.

Taylor R. 2009b. The performance of CAMPFIRE in Zimbabwe: 1989-2006. In: Child B, Suich $\mathrm{H}$, and Spenceley A, eds. Evolution and innovation in wildlife conservation in southern Africa. London: Earthscan, 201-222.

Thorn M, Scott DM, Green M, Bateman PW, and Cameron EZ. 2009. Estimating brown hyaena occupancy using baited camera traps. South African Journal of Wildlife Research 39:110.

Vilpoux OF. 2014. Agrarian reform and cooperation between settlers in the midwest of Brazil: an institutional approach. Land Use Policy 39:65-77.

Vincent V, and Hack HR. 1960. Land use and recommended farming systems for different land capability classes in different areas of Southern Rhodesia, In Annual conference of the 
professional officers of the Department of Research and Specialist Services. Government of Southern Rhodesia, Salisbury.

700 Waterloos E, and Rutherford B. 2004. Land reform in Zimbabwe: challenges and opportunities for poverty reduction among commercial farm workers. World development 32:537-553.

Wels H. 2003. Private wildlife conservation in Zimbabwe: joint ventures and reciprocity.

704

705

706 Leiden: Brill.

Willems W. 2004. Peasant demonstrators, violent invaders: representations of land in the Zimbabwean press. World development 32:1767-1783.

Williams S. 2007. Status of the cheetah in Zimbabwe. Cat News special Issue 3: status and conservation needs of cheetahs in southern Africa:32-36.

Williams ST. 2011. The impact of land reform in Zimbabwe on the conservation of cheetahs and other large carnivores. PhD thesis. Durham University. DOI 10.5281/zenodo.21001. Available from http://etheses.dur.ac.uk/3410/.

Williams ST. 2015a. Code for analysing spoor data. Accessed DOI 10.5281/zenodo.20991. Available from https://github.com/samual-williams/spoor-analysis.

Williams ST. 2015b. Spoor data. Open Science Framework. Accessed 22 July 2015. DOI 10.17605/OSF.IO/EHAZX. Available from https://osf.io/ehazx.

Woodroffe R. 2000. Predators and people: using human densities to interpret declines of large carnivores. Animal Conservation 3:165-173.

Woodroffe R, and Ginsberg JR. 1998. Edge effects and the extinction of populations inside protected areas. Science 280:2126-2128.

Woodroffe R, and Ginsberg JR. 2005. King of the beasts? Evidence for guild redundancy among large mammalian carnivores. In: Ray JC, Redford KH, Steneck RS, and Berger J, eds. 
721 Large carnivores and the conservation of biodiversity. Washington, DC: Island Press, $722 \quad 154-175$.

723 Woodroffe R, McNutt JW, and Mills MGL. 2004. African wild dog Lycaon pictus (Temminck, 724 1820). In: Sillero-Zubiri C, Hoffmann M, and Macdonald DW, eds. Canids: foxes, 725 wolves, jackals and dogs Status survey and conservation action plan. Gland:

726 IUCN/Species Survival Commission Canid Specialist Group.

727 Zinyama LM, Campbell DJ, and Matiza T. 1990. Land policy and access to land in Zimbabwe:

728 the Dewure resettlement scheme. Geoforum 21:359-370.

729 Zunga L. 2003. Farm invasions in Zimbabwe: is Zimbabwe a democracy? Randburg: Truth $730 \quad$ House Publishing. 


\section{Figures}

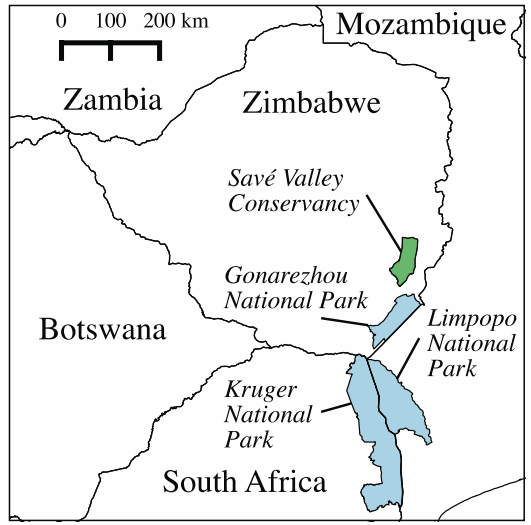

Legend

Transect

- Private

Resettlement

- Communal

Private

$\square$ Communal

$\square$ Resettlement

$\square$ Old resettlement
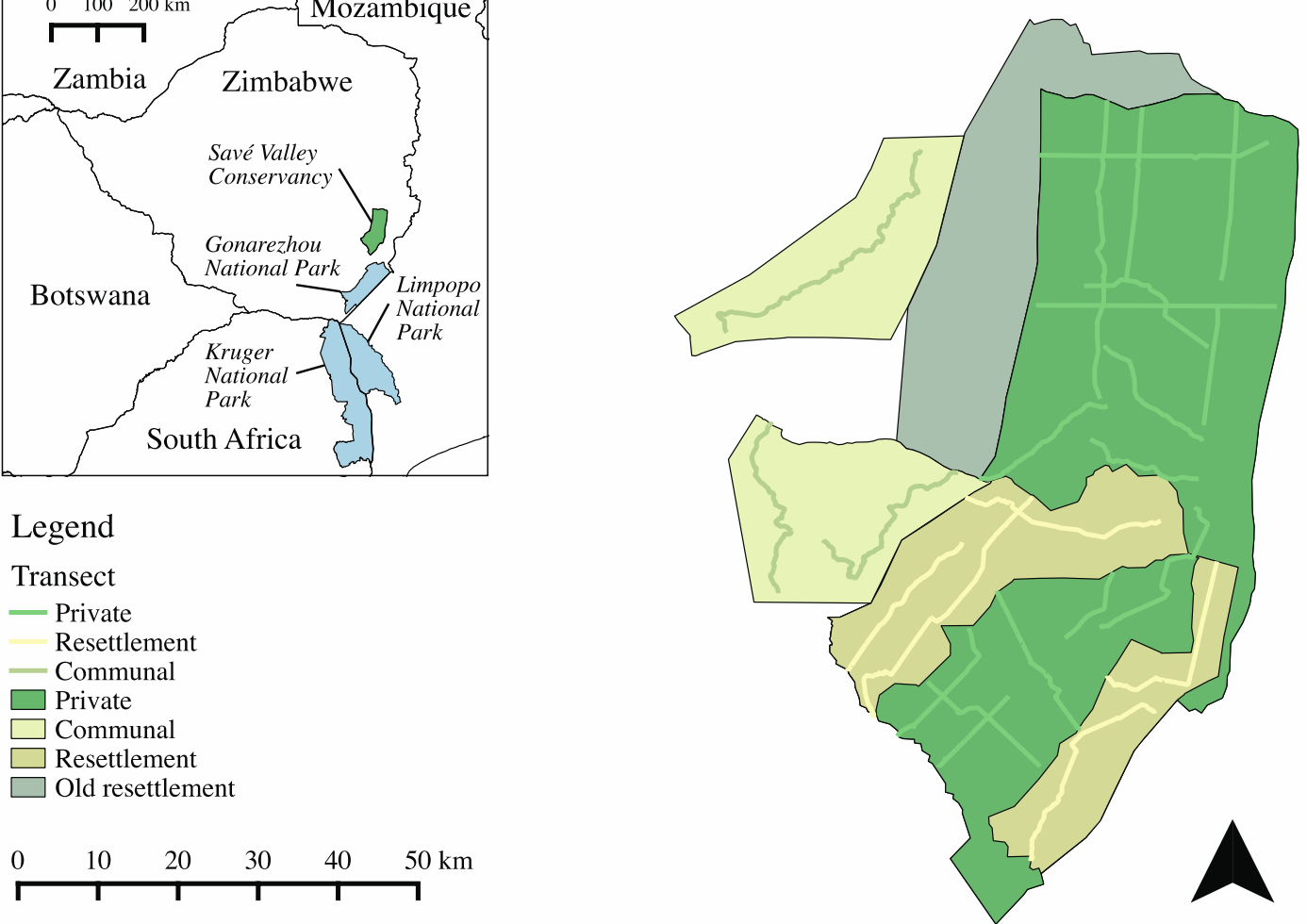

733

734 Figure 1. Land use types and spoor transects conducted at the study site in 2008. An old

735 resettlement area (settled in 1982) also shared a boundary with SVC, but was not included in this

736 study as it predated the FTLRP (Zinyama, Campbell \& Matiza, 1990). A total of 1,036 km of

737 transects were sampled. Inset map shows the location of Savé Valley Conservancy in relation to

738 Gonarezhou, Kruger and Limpopo National Parks and national boundaries. 

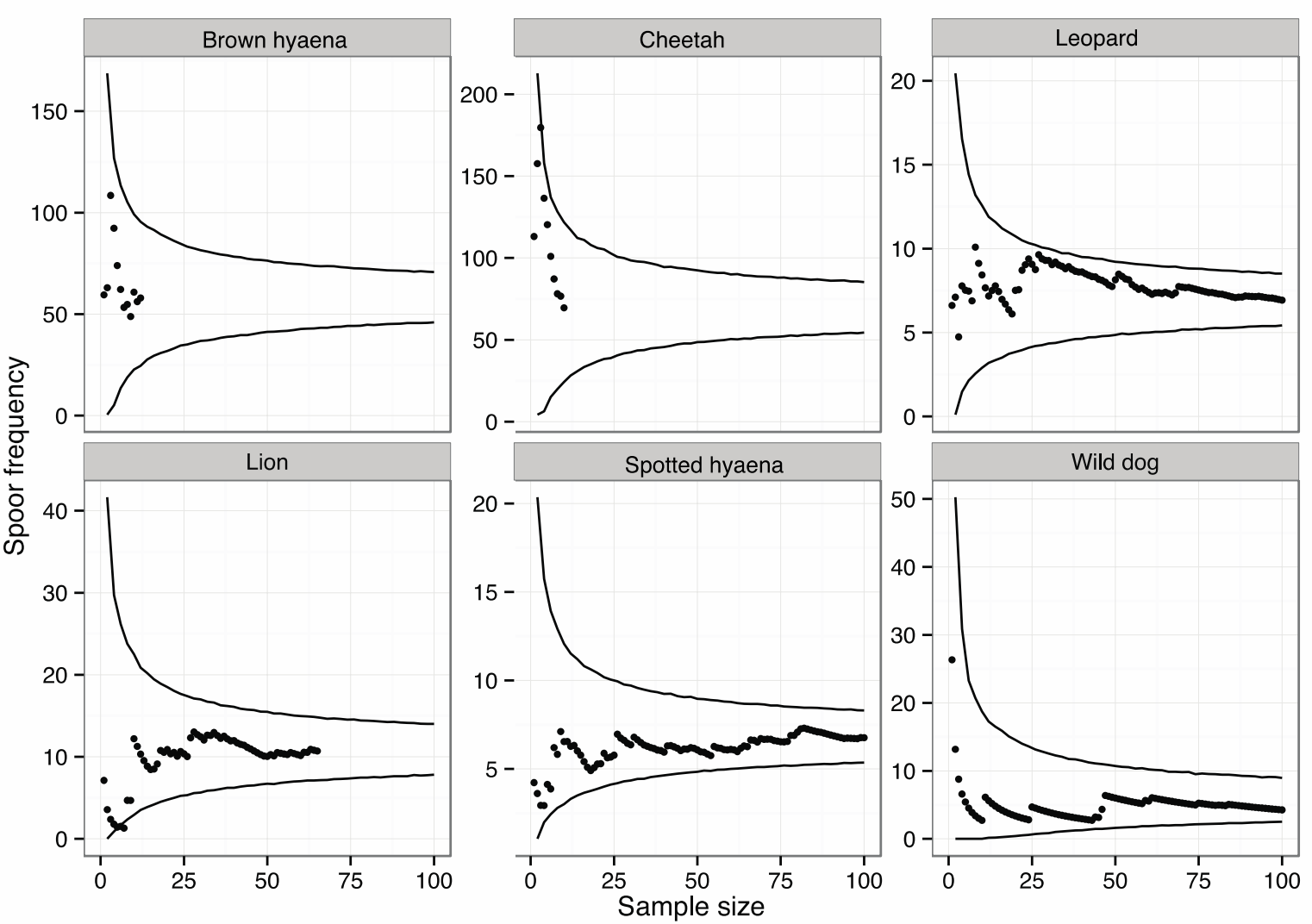

740

741 Figure 2. The relationship between spoor frequency and sampling effort for large carnivores on

transects on private land at Savé Valley Conservancy in 2008. Circles represent means and lines

743 represent $95 \%$ confidence intervals. Spoor sample size was 65 for lion, 101 for leopard, 10 for

744 cheetah, 129 for wild dog, 12 for brown hyaena and 106 for spotted hyaena. 


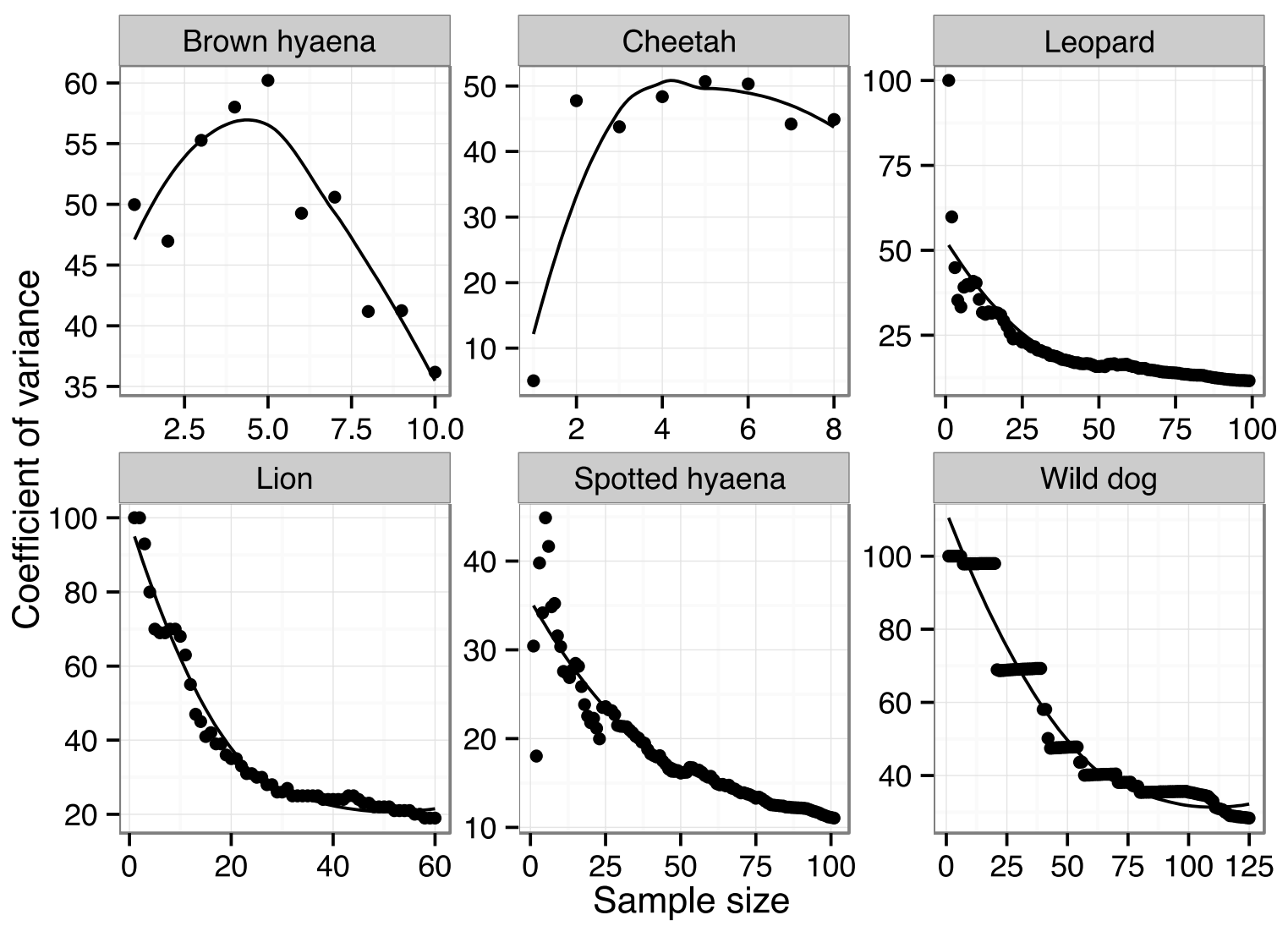

746

747 Figure 3. The relationship between coefficient of variance and sample size for large carnivores

748 on transects in private land on Savé Valley Conservancy in 2008. Spoor sample size was 65 for

749 lion, 101 for leopard, 10 for cheetah, 129 for wild dog, 12 for brown hyaena and 106 for spotted

750 hyaena.

751

752

753

754

755

756 


\section{Tables}

758 Table 1. Land distribution in Zimbabwe immediately before the onset of the FTLRP (2000) and

759 in May 2010. Adapted from (Scoones et al., 2010).

\begin{tabular}{lllll}
\hline Land use type & \multicolumn{2}{c}{2000} & \multicolumn{2}{c}{2010} \\
& $\begin{array}{l}\text { Area (million } \\
\text { ha) }\end{array}$ & $\begin{array}{l}\text { \% of total land } \\
\text { area }\end{array}$ & $\begin{array}{l}\text { Area (million } \\
\text { ha) }\end{array}$ & $\begin{array}{l}\text { of total land } \\
\text { area }\end{array}$ \\
\hline Large-scale private farms & 11.7 & 29.9 & 3.4 & 8.7 \\
Small-scale private farms & 1.4 & 3.6 & 1.4 & 3.6 \\
Old resettlement (1980-2000) & 3.5 & 9 & 3.5 & 9 \\
New resettlement (2000-present) & 0 & 0 & 7.6 & 19.5 \\
Communal land & 16.4 & 41.9 & 16.4 & 41.9 \\
National parks and forest land & 5.1 & 13 & 5.1 & 13 \\
Other land & 1 & 2.6 & 1.7 & 4.3 \\
\hline Total & 39.1 & 100 & 39.1 & 100
\end{tabular}


762 Table 2. Areas of each land use type in and around Savé Valley Conservancy, and survey effort

763 of spoor counts conducted in 2008 to determine the spoor density of large carnivores and other

764 mammals.

\begin{tabular}{lllll}
\hline Land Use Type & $\begin{array}{l}\text { Area } \\
\left(\mathrm{km}^{2}\right)\end{array}$ & $\begin{array}{l}\text { Sum of } \\
\text { transects } \\
(\mathrm{km})\end{array}$ & $\begin{array}{l}\text { Sample } \\
\text { penetration }\end{array}$ & $\begin{array}{l}\text { Total length } \\
\text { surveyed } \\
(\mathrm{km})\end{array}$ \\
\hline Private & 2,530 & 346 & 7.3 & $696^{\mathrm{a}}$ \\
Resettlement & 960 & 149 & 6.5 & 149 \\
Communal & 984 & 110 & 8.9 & 110 \\
\hline Total & 4,474 & 605 & & 955
\end{tabular}

765 aPrivate transects were each sampled twice in order to increase the sample size. On resettlement and communal land transects

766 were sampled only once as there were too few spoor recorded to make this necessary. 
768 Table 3. Population size and population density estimates for large carnivores across each LUT

769 in and around Savé Valley Conservancy in 2008. Values in parentheses represent 95\%

770 confidence intervals. Stander's (1998) leopard equation was used to calculate the estimates for

771 the leopard, while Stander's (1998) lion and wild dog equation was used to calculate the

772 estimates for all other species (see Williams, 2011).

\begin{tabular}{|c|c|c|c|c|c|c|}
\hline \multirow[b]{2}{*}{ Species } & \multicolumn{3}{|c|}{ Population density (animals $/ 100 \mathrm{~km}^{2}$ ) } & \multicolumn{3}{|c|}{ Population size } \\
\hline & Private & Resettlement & Communal & Private & Resettlement & Communal \\
\hline Cheetah & $0.44(0.41)$ & 0 & 0 & $11(10)$ & 0 & 0 \\
\hline Leopard & $7.64(1.73)$ & 0 & 0 & $193(44)$ & 0 & 0 \\
\hline Lion & $2.85(1.17)$ & 0 & 0 & $72(30)$ & 0 & 0 \\
\hline Wild dog & $5.65(3.19)$ & 0 & 0 & $143(81)$ & 0 & 0 \\
\hline Spotted hyaena & $4.51(1.05)$ & $0.61(0.44)$ & 0 & $114(27)$ & $6(4)$ & 0 \\
\hline Brown hyaena & $0.53(0.39)$ & 0 & 0 & $13(10)$ & 0 & 0 \\
\hline
\end{tabular}

773 
1

Land use types and spoor transects conducted at the study site in 2008.

An old resettlement area (settled in 1982) also shared a boundary with SVC, but was not included in this study as it predated the FTLRP ( Zinyama, Campbell \& Matiza, 1990) . A total of 1,036 km of transects were sampled. Inset map shows the location of Savé Valley Conservancy in relation to Gonarezhou, Kruger and Limpopo National Parks and national boundaries.

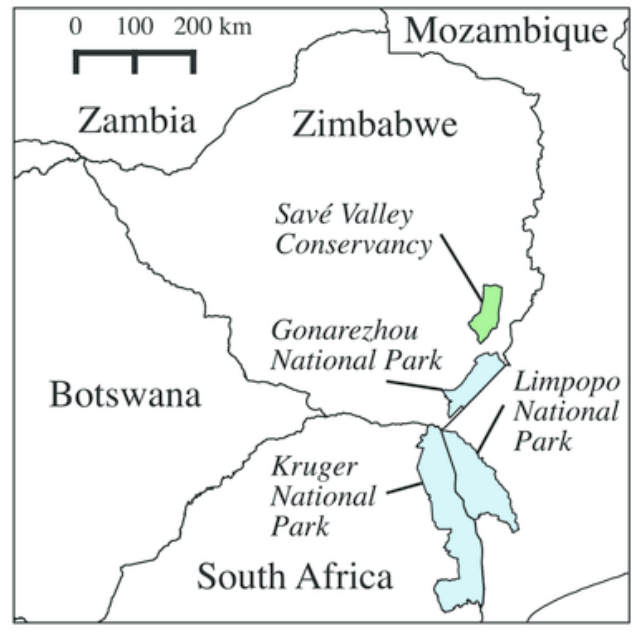

\section{Legend}

Transect

- Private

Resettlement

Communal

Private

Communal

Resettlement

Old resettlement
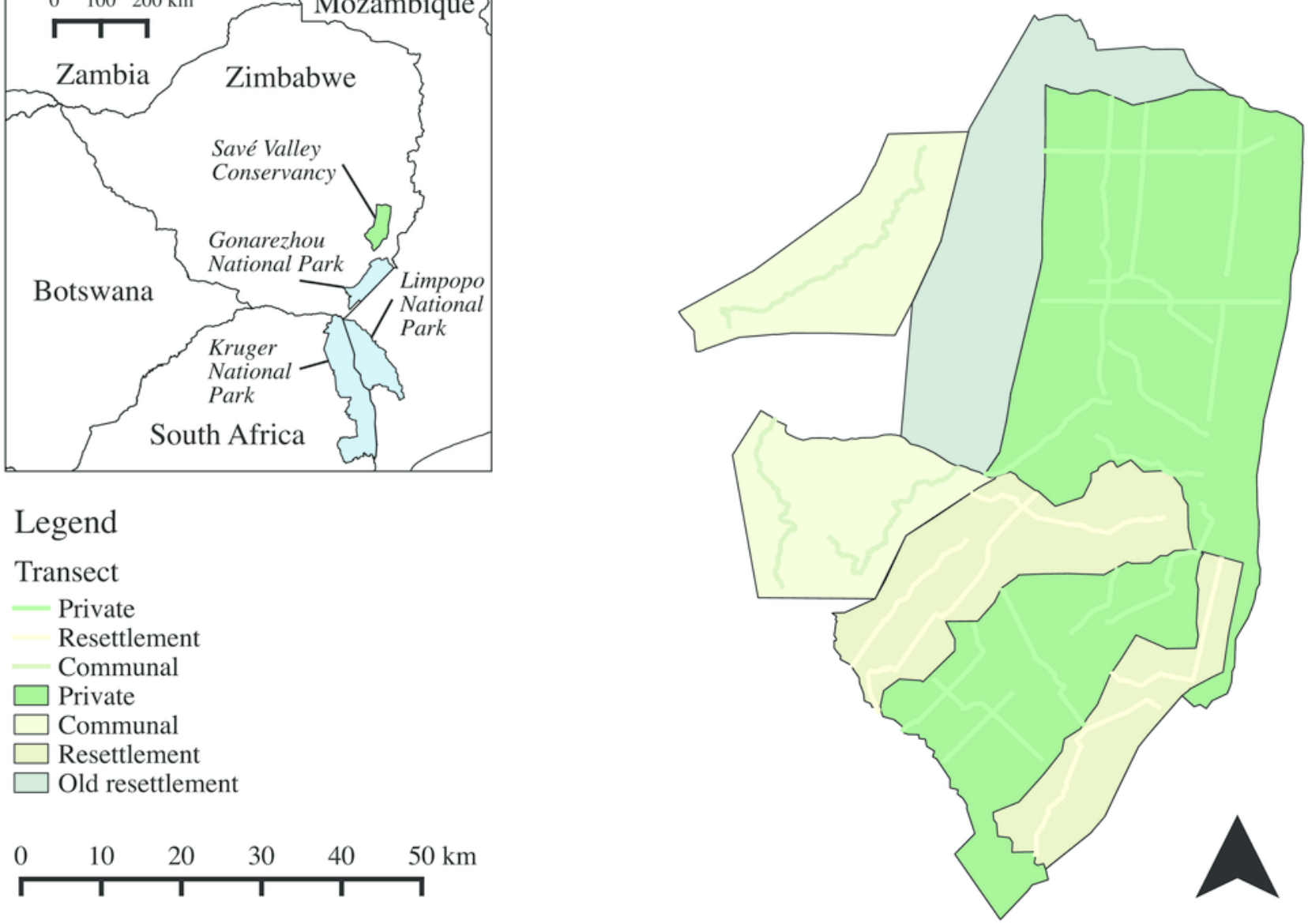
2

The relationship between spoor frequency and sampling effort for large carnivores on transects on private land at Savé Valley Conservancy in 2008.

Circles represent means and lines represent 95\% confidence intervals. Spoor sample size was 65 for lion, 101 for leopard, 10 for cheetah, 129 for wild dog, 12 for brown hyaena and 106 for spotted hyaena.
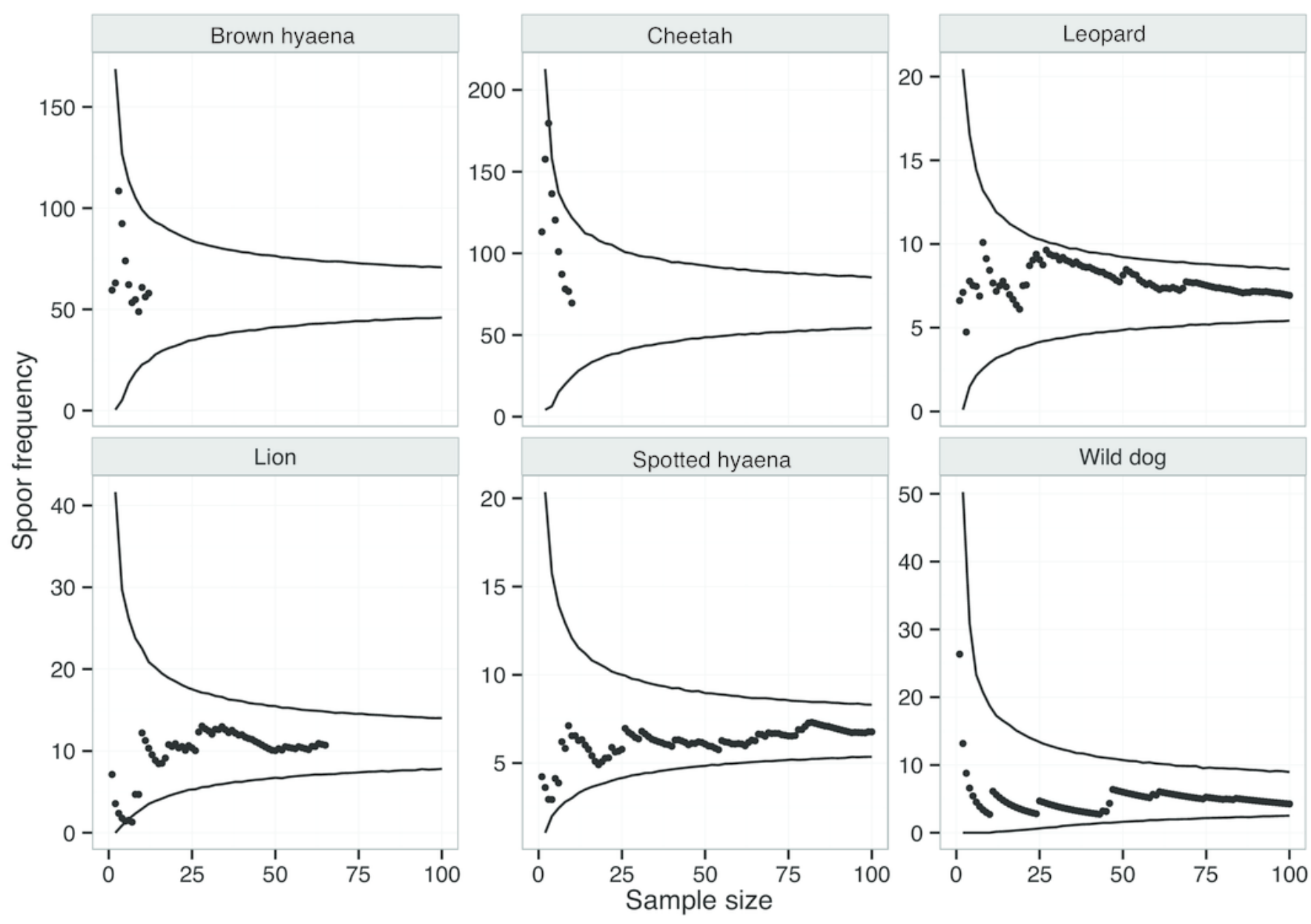


\section{3}

The relationship between coefficient of variance and sample size for large carnivores on transects in private land on Savé Valley Conservancy in 2008.

Spoor sample size was 65 for lion, 101 for leopard, 10 for cheetah, 129 for wild dog, 12 for brown hyaena and 106 for spotted hyaena.
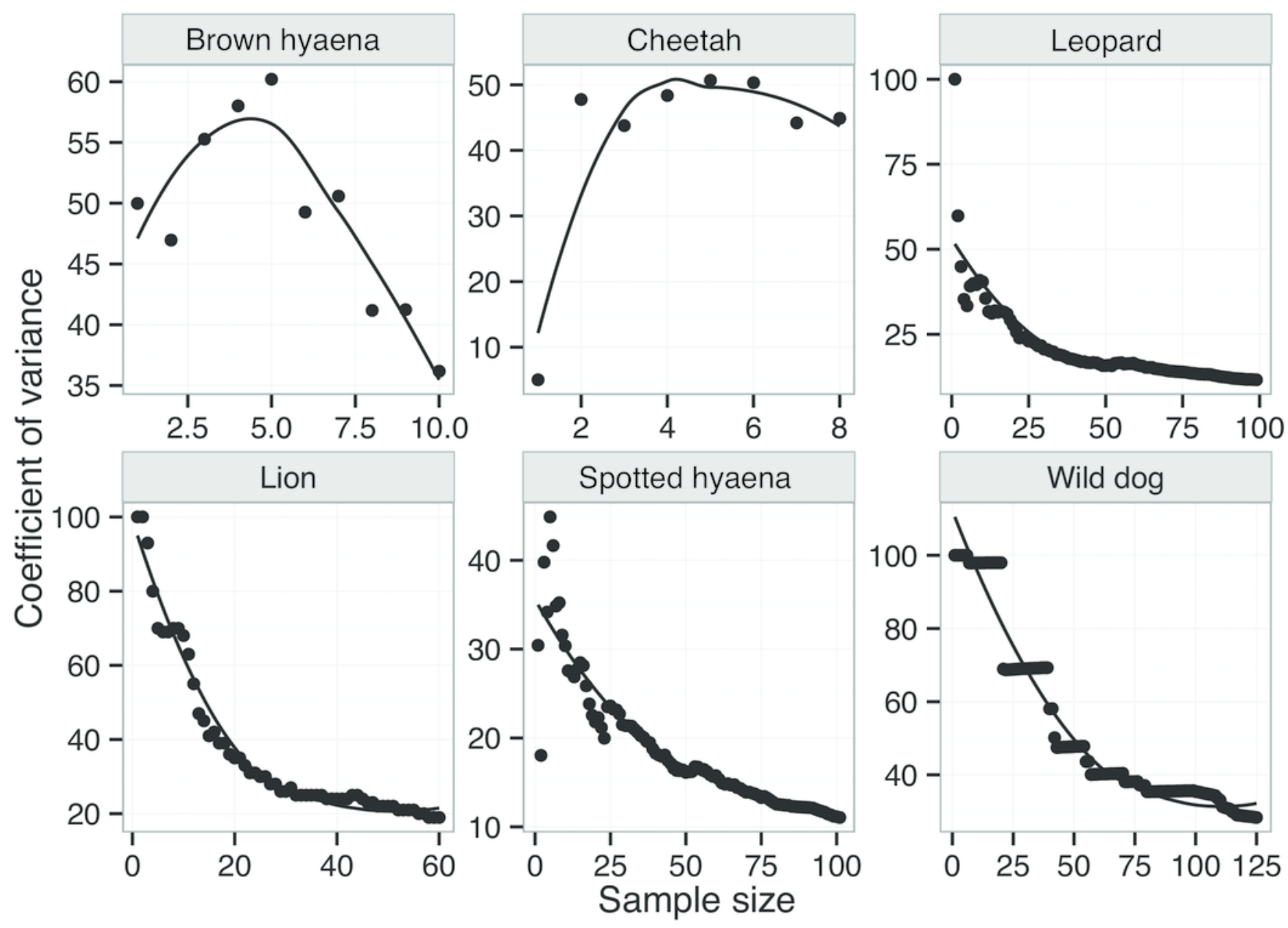


\section{Table $\mathbf{1}$ (on next page)}

Land distribution in Zimbabwe immediately before the onset of the FTLRP (2000) and in May 2010.

Adapted from ( Scoones et al., 2010 ) . 
1 Table 1. Land distribution in Zimbabwe immediately before the onset of the FTLRP (2000) and 2 in May 2010. Adapted from (Scoones et al., 2010).

\begin{tabular}{lllll}
\hline Land use type & \multicolumn{2}{c}{2000} & \multicolumn{2}{c}{2010} \\
& $\begin{array}{l}\text { Area (million } \\
\text { ha) }\end{array}$ & $\begin{array}{l}\text { \% of total land } \\
\text { area }\end{array}$ & $\begin{array}{l}\text { Area (million } \\
\text { ha) }\end{array}$ & $\begin{array}{l}\text { \% of total land } \\
\text { area }\end{array}$ \\
\hline Large-scale private farms & 11.7 & 29.9 & 3.4 & 8.7 \\
Small-scale private farms & 1.4 & 3.6 & 1.4 & 3.6 \\
Old resettlement (1980-2000) & 3.5 & 9 & 3.5 & 9 \\
New resettlement (2000-present) & 0 & 0 & 7.6 & 19.5 \\
Communal land & 16.4 & 41.9 & 16.4 & 41.9 \\
National parks and forest land & 5.1 & 13 & 5.1 & 13 \\
Other land & 1 & 2.6 & 1.7 & 4.3 \\
\hline Total & 39.1 & 100 & 39.1 & 100
\end{tabular}




\section{Table 2 (on next page)}

Table 2. Areas of each land use type in and around Savé Valley Conservancy, and survey effort of spoor counts conducted in 2008 to determine the spoor density of large carnivores and other mammals.

aPrivate transects were each sampled twice in order to increase the sample size. On resettlement and communal land transects were sampled only once as there were too few spoor recorded to make this necessary. 
1 Table 2. Areas of each land use type in and around Savé Valley Conservancy, and survey effort

2 of spoor counts conducted in 2008 to determine the spoor density of large carnivores and other

3 mammals.

\begin{tabular}{lllll}
\hline Land Use Type & $\begin{array}{l}\text { Area } \\
\left(\mathrm{km}^{2}\right)\end{array}$ & $\begin{array}{l}\text { Sum of } \\
\text { transects } \\
(\mathrm{km})\end{array}$ & $\begin{array}{l}\text { Sample } \\
\text { penetration }\end{array}$ & $\begin{array}{l}\text { Total length } \\
\text { surveyed } \\
(\mathrm{km})\end{array}$ \\
\hline Private & 2,530 & 346 & 7.3 & $696^{\mathrm{a}}$ \\
Resettlement & 960 & 149 & 6.5 & 149 \\
Communal & 984 & 110 & 8.9 & 110 \\
\hline Total & 4,474 & 605 & & 955
\end{tabular}

4 aPrivate transects were each sampled twice in order to increase the sample size. On resettlement and communal land transects

5 were sampled only once as there were too few spoor recorded to make this necessary. 


\section{Table 3(on next page)}

Population size and population density estimates for large carnivores across each LUT in and around Savé Valley Conservancy in 2008.

Values in parentheses represent 95\% confidence intervals. Stander's ( 1998 ) leopard equation was used to calculate the estimates for the leopard, while Stander's ( 1998 ) lion and wild dog equation was used to calculate the estimates for all other species ( see Williams, 2011 ) . 
1 Table 3. Population size and population density estimates for large carnivores across each LUT

2 in and around Savé Valley Conservancy in 2008. Values in parentheses represent 95\%

3 confidence intervals. Stander's (1998) leopard equation was used to calculate the estimates for

4 the leopard, while Stander's (1998) lion and wild dog equation was used to calculate the

5 estimates for all other species (see Williams, 2011).

\begin{tabular}{|c|c|c|c|c|c|c|}
\hline \multirow[b]{2}{*}{ Species } & \multicolumn{3}{|c|}{ Population density (animals/100km²) } & \multicolumn{3}{|c|}{ Population size } \\
\hline & Private & Resettlement & Communal & Private & Resettlement & Communal \\
\hline Cheetah & $0.44(0.41)$ & 0 & 0 & $11(10)$ & 0 & 0 \\
\hline Leopard & $7.64(1.73)$ & 0 & 0 & $193(44)$ & 0 & 0 \\
\hline Lion & $2.85(1.17)$ & 0 & 0 & $72(30)$ & 0 & 0 \\
\hline Wild dog & $5.65(3.19)$ & 0 & 0 & $143(81)$ & 0 & 0 \\
\hline Spotted hyaena & $4.51(1.05)$ & $0.61(0.44)$ & 0 & $114(27)$ & $6(4)$ & 0 \\
\hline Brown hyaena & $0.53(0.39)$ & 0 & 0 & $13(10)$ & 0 & 0 \\
\hline
\end{tabular}

6 